\title{
mpe
}

\section{U.S. Multinational \\ Corporations and the Mobility of Productive Capital: A Skeptical View}

\author{
TIM KOECHLIN \\ Department of Economics, Vassar College, Box 708, Raymond Avenue, \\ Poughkeepsie, NY 12604; e-mail: tikoechlin@vassar.edu
}

\begin{abstract}
This article calls into question the view that investment has become essentially "global" in recent decades. The data presented here suggest that productive capital is in fact remarkably immobile. This raises questions about the extent to which capital mobility constrains progressive projects. The article concludes by suggesting ways that we might clarify our understanding of the accumulation process and its potential political consequences.
\end{abstract}

JEL classification: F21; F23; F15

Keywords: globalization; capital mobility; direct foreign investment (DFI); U.S. multinational corporations

\section{Introduction}

Economists of most stripes agree that the processes of capitalist production and investment have become increasingly global in recent decades. Indeed, many argue that these processes have become essentially global. Advances in the technologies of transportation and communication-along with the aggressive pursuit of economic openness by governments, the International Monetary Fund (IMF), and the World Trade Organization (WTO) — have changed the geography of production in fundamental ways. Capital, goods, and services move across national borders with increasing ease. Or so the argument goes.

For neoclassicists and other mainstream economists, all of this is just fine: good news, in fact. Economic integration facilitates a more efficient allocation of resources and thus a larger economic pie. When it comes to globalization, more is better.

The heterodox story, in contrast, contends that globalization has enhanced the bargaining power of investors relative to just about everyone else, most notably workers, communities, and nation-states. The increasing mobility of capital has left workers and states with a daunting 
choice: accommodate the demands of footloose multinational corporations (MNCs) or watch capital and jobs flee. The result is a "race to the bottom": wage erosion, deteriorating economic security, and greater limits on the ability of states to regulate MNCs and other global investors.

This story tends to conflate two related issues. First, how does globalization change the dynamics of capitalist production and distribution? And, second, how fast is all of this happening? This article argues that we on the Left have done a better job of answering the first question than the second. That is, neoliberal globalization does tend to enhance the bargaining power of capital in a variety of ways, but the pace, extent, and thus the consequences of globalization are routinely overstated and misstated.

The "race to the bottom" story hinges crucially on the mobility of capital; globalization has disempowered workers and nation-states because firms can relocate with increasing ease. In this article, I argue that the available evidence suggests that productive capital is in fact remarkably immobile. Although the investment process has become increasingly "global" by most reasonable measures, it is far from perfectly global. Indeed, one might reasonably argue that capital accumulation remains an essentially national phenomenon.

My primary focus here is on the behavior of MNCs, especially U.S. MNCs. The data presented here are persuasive, I think, but they also leave a number of questions unanswered. The final two sections of the article address some of the limitations of this analysis and point to a few important questions about the accumulation process and its consequences.

The issues raised in the article are of academic interest for sure, but they also have potentially important political implications. Efforts to create a more equitable economy need to be rooted in a clear understanding of the process of capital accumulation and the terms of class and nonclass struggle. And so it is crucial that we develop a realistic sense of the implications of international investment.

\section{U.S. Direct Foreign Investment and U.S. Multinational Corporations}

U.S. direct foreign investment (DFI)—-long-term investment by U.S. MNCs-has grown quite dramatically during the postwar years. The stock of U.S. DFI grew from $\$ 32$ billion in 1960 to $\$ 427$ billion in 1990 to $\$ 2,063$ billion in 2004 (Bureau of Economic Analysis [BEA] various years). The world stock of DFI—DFI by MNCs from all countrieshas grown even faster (United Nations Conference on Trade and Development [UNCTAD] various years).

It turns out that these many billions of dollars of U.S. DFI represent a relatively small share of all U.S. investment. The ratio of annual U.S. DFI outflows to all investment by U.S. firms - one reasonable measure of the propensity of U.S. firms to engage in DFIaveraged just 4.6 percent for 1960-1991 (Koechlin 1995: 94). Between 1991 and 2004, this ratio averaged 7.4 percent (UNCTAD 2005). From 1991 to 2004, U.S. DFI in poor countries ("developing economies" in UNCTAD) as a share of all investment by U.S. firms was just 2.5 percent: a slight increase above 1960-1991, when it averaged about 2.2 percent (author's calculation from data in UNCTAD various years).

The ratio of DFI to domestic investment has generally been a bit higher for rich countries as a group than for the United States (Sutcliffe and Glyn 2003; Koechlin 1995). For the years 2001-2004, the ratio for "developed countries" as a group was 11.5 percent, whereas 
the ratio for the United States was 7.3 percent. The ratio for "the world" was 8.9 percent during this period (UNCTAD 2003, 2005).

In short, DFI has been, and remains, a very small share of all investment. The overwhelming bulk of investment is domestic investment, more than 90 percent in the U.S. case. Generally speaking, the propensity of firms to engage in DFI has grown throughout time but, generally speaking, very slowly. And the share of all U.S. investment going to poor countries is very low, and it does not appear to be growing very rapidly. One might reasonably conclude that U.S. firms appear reluctant to invest abroad!

When U.S. firms do invest outside of the United States, where do they go? As of 2004, about 70 percent of the stock of U.S. DFI was in other rich countries (Koncz and Yorgason 2005: 50). This share has declined slightly in recent years: in 1980, about 75 percent of the stock of U.S. DFI was in rich countries. The share of European DFI in rich countries in 2004 was 77 percent, a bit higher than the U.S. share (UNCTAD 2005).

What about DFI in manufacturing? Flows of U.S. manufacturing DFI have grown throughout time, but these flows have declined relative to all U.S. DFI and relative to all U.S. investment. In 2004, the share of the U.S. DFI stock in manufacturing was 20.7 percent of the overall U.S. DFI stock, down from 35.4 percent in 1994 (Koncz and Yorgason 2005: 51; BEA 1994: 103). In 2004, 75.5 percent of the U.S. DFI stock in manufacturing was located in rich countries, a bit higher than the share of U.S. DFI in all industries (Koncz and Yorgason 2005: 50).

The bulk of U.S. DFI in poor (or "developing") countries is concentrated in a relatively few countries. In 2004, 31 percent of the stock of U.S. DFI in poor countries was located in just four countries: Mexico, Singapore, Brazil, and Hong Kong. An additional 11 percent was located in five countries: China, Malaysia, Taiwan, Argentina, and Chile (Lowe 2005: 136). The share of U.S. DFI going to poor countries has grown slightly, and a few countries-most notably, Mexico and China-have experienced significant increases. But these surges represent a small share of U.S. DFI and a tiny share of capital formation by U.S. firms. In 2004, U.S. DFI in China represented less than 1 percent of the U.S. DFI stock, while U.S. DFI in Mexico represented 3.2 percent of the U.S. DFI stock in all countries (Lowe 2005: 136).

Just 0.8 percent of the world stock of DFI is located in the world's poorest countries (i.e. fifty countries categorized as "least developed" in UNCTAD 2005: 307). DFI inflows are, however, quite substantial relative to domestic investment in these countries. The ratio of inward DFI (from all sources) to gross fixed capital formation in the LDCs averaged more than 10 percent for 1997-2004. During the same period, the ratio of inward DFI to gross fixed capital formation was 12.2 percent for all "developing economies" (excluding China; UNCTAD 2005: 324).

Sixty-six percent of the output of U.S. foreign affiliates is sold locally; that is, to customers in an affiliate's host country. Twenty-three percent is sold to customers in "third countries" (countries other than the United States or the host country). Just 11 percent of the output of U.S. affiliates is sold to U.S. consumers. Local sales account for a similar proportion of sales by U.S. affiliates in poor countries: 71 percent in "Asia and Pacific," 66 percent in Latin America, and 62 percent in Africa (Mataloni and Yorgason 2002: 38).

Other indicators of the geography of MNC activity tell a similar story. In 1982, foreign affiliates of U.S. MNCs employed 6.6 million workers, equivalent to about 6 percent of the U.S. labor force at the time. In 2003, U.S. MNCs employed 9.9 million workers abroad, equivalent to 6.9 percent of the U.S. labor force (Mataloni 2005: 10). In 2001, 
62 percent of the employees of U.S. affiliates abroad were in "high wage countries," down from 70 percent in 1977 (Mataloni 2004: 53). In 2001, employees of U.S. foreign affiliates in poor countries were equivalent to about 2.6 percent of the U.S. labor force.

The output (value added) of U.S. foreign affiliates was $\$ 705$ billion in 2003, equivalent to 6.4 percent of U.S. GDP. Of this $\$ 705$ billion, 81 percent was produced in rich countries (Mataloni 2005: 10). In that same year, value added by U.S. foreign affiliates as a share of host country GDP was less than 5 percent for all but nine host countriesIreland, Singapore, Canada, Nigeria, Honduras, the United Kingdom, Belgium, Hong Kong, and Malaysia — and less than 10 percent for all but two-Ireland and Singapore (Mataloni 2005: 17).

Even U.S. MNCs per se appear to be anchored to the United States, and this has changed little during the past quarter century. In 2003, U.S. "parents" accounted for 74 percent of total production of U.S. MNCs, down from 75 percent in 1977; 74 percent of total capital expenditures, down from 79 percent in 1977; and 74 percent of total employment, down from 78 percent in 1977 (Mataloni 2005: 10).

These data tell a remarkable and remarkably consistent story. The extent of the globalization process - by several measures - appears to be shockingly limited, and the globalization of investment appears to be growing very slowly over time. U.S. firms, and firms from other countries as well, invest overwhelmingly at home. The share of DFI in overall investment has grown, but it remains quite low. When U.S. firms venture abroad, they invest and produce overwhelmingly in rich countries, and they sell most of their output to customers in the host country, even when that host country is a low-wage country. And when U.S. MNCs do invest in "poor" countries, they generally do not invest in the poorest of the poor but, rather, in a few relatively high-income countries. And finally, DFI in manufacturing does not appear to have become more important throughout time.

\section{Responsiveness and Outsourcing}

Claims about the consequences of capital mobility hinge on the assumption that investment is highly responsive to national differences in rates of return, labor costs, institutional arrangements, and other aspects of the "investment climate." The data presented above are suggestive, but they do not directly answer a central question: how responsive is productive investment to differences between and among national investment climates?

This important question has received less scholarly attention than it deserves, but the existing literature is largely consistent with the data presented above. Epstein (1996), for example, showed that affiliates of U.S. MNCs-which we might expect to be especially footloose - do not appear to respond to international rate of return differentials. Koechlin (1992) found that, for 1960-1985, domestic investment within each of the seven largest capitalist countries (the G7) was generally unresponsive to foreign rates of return. Gordon (1988) found that manufacturing profit rates (1952-1983) for the seven largest capitalist countries showed no tendency to converge over time. Rates of return on DFI by MNCs from firms based in the G7 countries continue to vary widely (Organization for Economic Cooperation and Development 2005: 41). A few studies, however, suggest that investment and employment in poor countries may be responsive to changes in relative wage rates (e.g., Larudee 2002; Gruben 1990). 
What about the outsourcing of production by MNCs to firms in poor countries? Outsourcing is particularly relevant to this discussion because (1) it represents an apparently close substitute for DFI, (2) it does not show up in the DFI data, and (3) it appears that outsourcing is increasingly important. We know, for instance, that there has been a significant surge in manufacturing exports from poor countries during the past twenty-five years (Pollin 2003: 155).

A careful discussion of outsourcing and its possible implications is beyond the scope of this article, but I can shed some light on this issue by looking at recent trade data.

The share of imported goods in U.S. gross domestic purchases increased from 7.5 percent in 1977 to 11 percent in 2003 (Mataloni 2004: 54). In 2003, goods imports from poor countries accounted for 4.8 percent of U.S. gross domestic purchases. U.S. imports of manufactured goods as a share of "apparent consumption" (production plus imports minus exports) increased from 6 percent in 1974 to 21 percent in 1999. U.S. imports from poor countries accounted for 9 percent of apparent consumption of manufactured goods in 1999 (Sutcliffe and Glyn 2003: 65).

Not all of these imports were the result of outsourcing, of course. In 2003, 22 percent of U.S. goods imports originated with U.S. affiliates abroad, and, furthermore, some imports originated with foreign firms with which U.S. MNCs have no relationship (Mataloni and Yorgason 2002: 38). All of this suggests that outsourcing accounts for somewhat less than 4.8 percent of U.S. gross domestic purchases and somewhat less than 9 percent of apparent consumption of manufactured goods.

This analysis is a bit rough, for sure, but it does provide some sense of the possible scale of outsourcing. And, like the DFI data, it provides little support for sweeping claims about the globalization of production.

\section{Caveats, Questions, and a Conclusion}

I have argued throughout this essay that the data-especially data on the behavior of MNCs - suggest that the process of capital accumulation is much less global than we tend to presume. But it is also clear that there are a number of unresolved questions regarding capital mobility and its consequences. And so some caveats are in order.

It may be, first off, that a little capital mobility goes a long way. That is, it may be that the current level of capital mobility provides the basis for a viable threat, and this "threat effect" may have tipped the balance of power toward MNCs in a fairly dramatic way. Kate Bronfenbrenner (1996), in a study of 525 organizing campaigns (1993-1995), found that employers threatened plant closings in 271 cases ( 52 percent), and "more than 10 percent of organizers we interviewed reported that the employer directly threatened to move to Mexico if the workers were to organize" (Bronfenbrenner 1996: 11).

Second, globalization's effects vary from industry to industry. It may be that high degrees of mobility in a few key industries can have a chilling effect on the working class as a whole. The auto and steel industries come to mind: both highly unionized, and both deeply affected by international competition in ways that have shaken workers in these industries and others.

It is also true that the extent and consequences of globalization vary from country to country. The argument I have made here is most compelling for the United States, which is among the world's most closed economies. 
Furthermore, I have not considered the significance of financial capital, which is unquestionably more mobile than productive capital, and which can surely constrain the ability of governments to pursue egalitarian macroeconomic policy (Crotty 1993).

Fifth, why - despite stunning advances in technology — is productive capital so immobile? What are the sources of this friction?

And, finally, while capitalist production is far from "perfectly global," and while capital is not drawn predominantly to low-wage sites, it appears to be the case that globalization has undermined the bargaining power of workers in the United States and the world over. And a little wage erosion - that is, somewhere between none and whatever we might imagine from a rapid "race to the bottom"-matters. And so, although we may not be "racing" toward wage equalization and institutional convergence, globalization surely complicates the struggle for a fair, equitable economy.

But notice that these caveats and questions do not contradict the evidence presented in the first half of the article. They indicate, rather, that we need to do more work to understand the extent and consequences of investment globalization.

What difference does all of this make? For heterodox economists, investment is about more than enlarging the capital stock. The process of capital accumulation is innately political: it reflects and alters the relationships between and among classes and nationstates. This article suggests that we need to think more carefully about the process of accumulation and its geography.

David Gordon (1988) reached a similar set of conclusions in his terrific empirical analysis of "globalization" nearly twenty years ago. In his conclusion, Gordon argued that exaggerated claims about globalization have helped to foster a "spreading fatalism in the advanced countries." He continued,

Transnational Corporations are neither all-powerful nor fully equipped to shape a new world economy all by themselves. ... Workers and consumers . . . are once again in a position to bargain over institutional transformation. The global economy is up for grabs.... The opportunity for enhanced popular power remains ripe. (Gordon 1988: 64)

\section{References}

Bronfenbrenner, K. 1996. Effects of plant closing or threat of plant closing on the right of workers to organize. Report to the Labor Secretariat of the North American Commission for Labor Cooperation. Ithaca, NY: Cornell University, New York School of Industrial and Labor Relations.

Bureau of Economic Analysis (BEA). 1994. US direct investment abroad: Benchmark survey, 1994. Washington, DC: U.S. Department of Commerce.

—. Various years. US direct investment abroad: Benchmark survey. Washington, DC: U.S. Department of Commerce.

Crotty, J. 1993. The rise and fall of the Keynesian revolution in the age of the global marketplace. In Creating a new world economy, ed. G. Epstein, J. Graham, and J. Nembhard, 163-81. Philadelphia: Temple University Press.

Epstein, G. 1996. International capital mobility and the scope for national economic management. In States against markets, ed. R. Boyer and D. Drache, 211-26. New York: Routledge.

Gordon, D. 1988. The global economy: New edifice or crumbling foundations? New Left Review 168 (March/April): 24-65. 
Gruben, W. 1990. Mexican and maquiladora growth: Does it cost US jobs? Federal Reserve Bank of Dallas Economic Review (January): 15-29.

Koechlin, T. 1992. The responsiveness of investment to foreign economic conditions. Journal of Post Keynesian Economics 6 (2): 203-16.

1995. The globalization of investment. Contemporary Economic Policy 13: 92-100.

Koncz, J., and D. Yorgason. 2005. Direct investment position for 2004: Country and industry detail. Survey of Current Business (July): 40-53.

Larudee, M. 2002. Inequality and its remedies in an age of integration. In Integration in the Americas Conference proceedings. Albuquerque: University of New Mexico. http://laii.unm.edu/conference/larudee.php.

Lowe, J. 2005. US direct investment abroad: Detail for historical-cost position and related capital and income flows, 2004. Survey of Current Business (September): 117-54.

Mataloni, R. 2004. A note on patterns of production and employment by US multinational companies. Survey of Current Business (March): 52-56.

- 2005. US multinational companies: Operations in 2003. Survey of Current Business (July): 9-29.

Mataloni, R., and D. Yorgason. 2002. Operations of US multinational companies: Preliminary results from the 1999 benchmark survey. Survey of Current Business (March): 24-54.

Organization for Economic Cooperation and Development. 2005. Economic globalisation indicators. New York: OECD.

Pollin, R. 2003. Contours of descent. New York: Verso.

Sutcliffe, B., and A. Glyn. 2003. Measures of globalization and their misinterpretation. In The handbook of globalization, ed. J. Michie, 61-78. Northampton, MA: Edward Elgar.

United Nations Conference on Trade and Development (UNCTAD). 2003. World investment report, 2003. New York: United Nations.

- 2005. World investment report, 2005. New York: United Nations.

Various years. World investment report. New York: United Nations.

Tim Koechlin is a visiting associate professor of economics at Vassar College. In addition to his work in economics, he is also a contributor to Vassar's programs in international studies, urban studies, and Latin American and Latino studies. Koechlin has published papers on a variety of topics, including globalization, the determinants of investment, NAFTA, and the effects of trade on employment and wages. 